\section{Nitrogen Form and Solution pH Effects on Root Anatomy of Cranberry}

\author{
Chad E. Finn', Carl J. Rosen ${ }^{2}$, and James J. Luby ${ }^{3}$ \\ University of Minnesota, Saint Paul, MN 55108
}

Additional index words. nitrate, ammonium, Vaccinium macrocarpon

\begin{abstract}
Root sections of cranberry (Vaccinium macrocarpon Ait. cv. Searles) were microscopically examined to document the typical anatomy of cranberry roots and changes in root anatomy in response to $\mathrm{N}$-form and solution $\mathrm{pH}$. Cranberry cuttings were rooted, then established in hydroponic conditions with three $\mathrm{N}$ and two $\mathrm{pH}$ regimes. The three $\mathrm{N}$ regimes with equal $\mathrm{N}$ levels were 1) $\mathrm{NH}_{4}-\mathrm{N}$ alone, 2) $\mathrm{NH}_{4} / \mathrm{NO}_{3}-\mathrm{N}$ in combination, or 3) $\mathrm{NO}_{3}-\mathrm{N}$ alone. $\mathrm{pH}$ was maintained at 4.5 or 6.5. Root apical regions were examined using phase contrast, bright field, and epifluorescence microscopy. The cranberry root tip develops with a closed apical organization with the tetrarchal vascular cylinder, cortex, and root cap traceable to independent meristem cell layers. The most obvious treatment difference was an accumulation of unidentified "granules" in the subepidermal layer, readily visible with epifluorescence microscopy with $\mathrm{NO}_{3}-\mathrm{N}$ alone. Roots produced at $\mathrm{pH} 4.5$ branched less than those at 6.5 and had more "quiescent" root initials; at $\mathrm{pH} 6.5$, these developed more frequently into branch roots.
\end{abstract}

Root morphogenesis of Vaccinium species has been shown to be affected by $\mathrm{N}$-form and solution $\mathrm{pH}$. Medappa and Dana (1970) reported that cranberry roots became darker, thicker, and more branched as $\mathrm{pH}$ increased

Received for publication 30 Nov. 1989. Scientific Journal series paper no. 17,965 Minn. Agr. Expt. Sta., St. Paul. The efforts of Chris Cole in reviewing the anatomical description of the microscopic sections examined in this experiment are gratefully acknowledged. The cost of publishing this paper was defrayed in part by the payment of page charges. Under postal regulations, this paper therefore must be hereby marked advertisement solely to indicate this fact.

'Research Assistant, Dept. of Horticultural Science. Present address: Dept. of Horticulture, University of Missouri, Columbia, MO 65211.

${ }^{2}$ Associate Professor, Dept. of Soil Science.

Associate Professor, Dept. of Horticultural Science. from 4 to 8 . Similar responses to $\mathrm{pH}$ have also been reported in blueberry (Townsend, 1967, 1969, 1971). Nitrate-N, as the sole form of $\mathrm{N}$, appears to stunt cranberry root and shoot growth compared to $\mathrm{NH}_{4}-\mathrm{N}$ (Rosen et al., 1990). Addoms and Mounce (1932) examined the effects of $\mathrm{N}$ form and $\mathrm{pH}$ on cranberry growth. Although they presented a drawing of a cranberry root in cross section, they did not relate the root anatomy to treatment effects. Nieuwdorp (1969), concentrating on endomycorrhizal infection of cranberry roots, published a drawing depicting cranberry root tip anatomy. We did not find any photographs of cranberry root anatomy in the literature. The objectives of this study, therefore, were to document cranberry root anatomy using various staining techniques and to determine whether root anatomy changes in response to $\mathrm{N}$-form and solution $\mathrm{pH}$. A solution culture system was used in this experiment to obtain greater control of the treatments and cleaner root sample preparations than from a soil culture system.

Root material from 'Searles' cranberry was collected from a hydroponic experiment previously described in detail (Rosen et al., 1990). Briefly, treatments were initiated by transferring rooted cuttings to constantly aerated 7-liter vessels containing one of three modified Hoagland nutrient solutions adjusted to a $\mathrm{pH}$ of either 4.5 or 6.5 . Nitrogen and $\mathrm{pH}$ treatments were: 1$) \mathrm{NH}_{4}-\mathrm{N}, 4.5 ; 2$ ) $\mathrm{NH}_{4}-\mathrm{N} / \mathrm{NO}_{3}-\mathrm{N}, 4.5$; 3) $\mathrm{NO}_{3}-\mathrm{N}, 4.5$; 4) $\mathrm{NH}_{4}^{-}$ $\mathrm{N}, 6.5$; 5) $\mathrm{NH}_{4}-\mathrm{N} / \mathrm{NO}_{3}-\mathrm{N}, 6.5$; and 6) $\mathrm{NO}_{3}-$ $\mathrm{N}, 6.5$. All $\mathrm{N}$ concentrations were initially adjusted to $2 \mathrm{~mm}$. Solutions were changed every 2 weeks and $\mathrm{pH}$ was adjusted daily, using $\mathrm{Ca}(\mathrm{OH})_{2}$ or $\mathrm{H}_{2} \mathrm{SO}_{4}$. Nitropyrin, a vitrification inhibitor, added to all solutions at the rate of $4 \mu \mathrm{M}$, successfully inhibited conversion of ammonium to nitrate.

Samples from the apical $3 \mathrm{~cm}$ of roots were harvested to obtain at least 100 root tips from each treatment. The samples were collected from two randomly selected plants from each treatment 12 weeks after treatment initiation. All of the samples were fixed in CRAF and embedded in Paraplast. Twenty to 30 root tips were sectioned with a microtome at 8 to $10 \mu \mathrm{m}$ and mounted on glass slides. The mounted sections were processed through a staining series that included $75 \mathrm{~min}$ in safranin and 7 to $10 \mathrm{sec}$ in fast green. Both longitudinal and cross sections were examined using bright field, phase contrast, and epifluorescent microscopy.

The anatomy of cranberry roots, grown under the conditions of this study, parallels the drawings presented by Addoms and Mounce (1932) and Nieuwdorp (1969). A cranberry root tip appears to most closely resemble the closed type of apical organization described by Esau (1960) and Fahn (1982) (Fig. 1, top). In a closed system, the vascular cylinder, the cortex, and the root cap are traceable to independent layers of cells in the apical meristem, with the epidermis differentiating from the outermost layer of the cortex. The tip consists of the root cap 

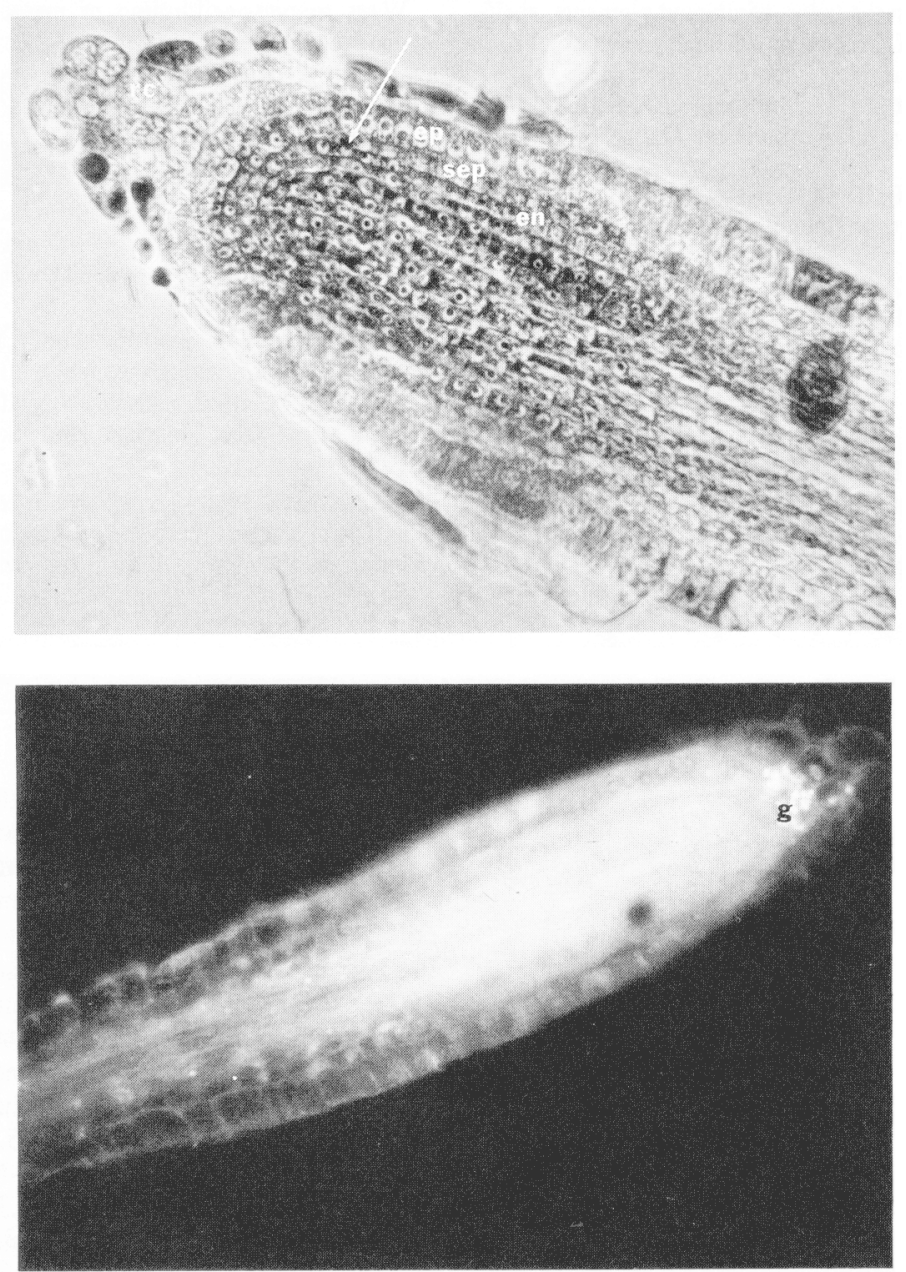

Fig. 1. Photomicrographs of a V. macrocarpon root tip in long section from plants grown with $\mathrm{NH}_{4}-\mathrm{N} / \mathrm{NO}_{3}-\mathrm{N}$ at $\mathrm{pH}$ 4.5. (top) Phase contrast microscopy $(\times 400)$; ep $=$ epidermal layer, en $=$ endodermal layer, $\mathrm{rc}=$ root cap cells, $\mathrm{sep}=$ subepidermal layer. Arrow indicates layer from which endodermis and subepidermis arisc. (bottom) Epifluorescence microscopy $(\times 400) ; \mathrm{g}=$ "granules".

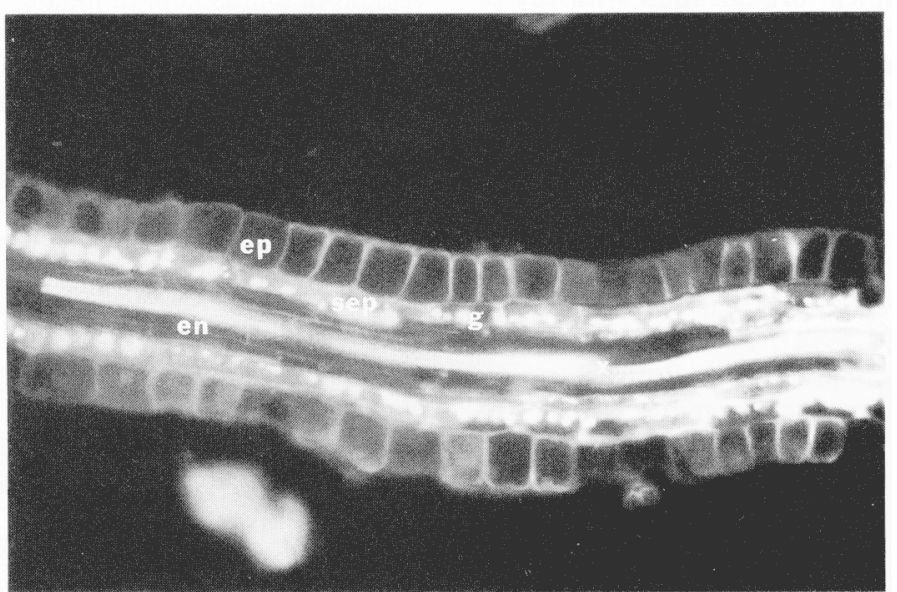

Fig. 2. Photomicrograph of $V$. macrocarpon root in long section $(\times 400$, cpifluorescence) from plants grown with only $\mathrm{NO}_{3}-\mathrm{N}$ at $\mathrm{pH}$ 6.5. ep = Epidermal layer, en = endodermal layer, $\mathrm{g}=$ "granulcs", sep $=$ subbepidermal layer, and $\mathrm{x}=\mathrm{xylem}$.

cells, an epidermal layer, a subepidermal layer, an endodermal layer, and the vascular cylinder containing the cells that have begun to elongate and differentiate into xylem and phloem (Fig. 1, top). The subepidermal layer appears to arise from a division within the endodermal layer. Under epifluorescence not clearly visible (Fig. 1, top). Plant anatomy texts report the presence of statoliths (amyloplasts containing starch) within root cap cells (Esau, 1960; Fahn, 1982). Statoliths are hypothesized to be partly responsible for geotropic perception in roots (Esau, 1960; Fahn, 1982; Marschner, 1986; Moore and Evans, 1986; Salisbury and Ross, 1985). If these granules are in fact statoliths, their presence in cells other than root caps and their seemingly random distribution throughout the individual cells are unusual (Moore and Evans, 1986). These fluorescing granules occurred to some extent in all of the root tips examined, regardless of treatment. The nature of these fluorescing granules in the root tip is unknown.

In later stages of development, the roots consist of a distinguishable epidermis, subepidermis, endodermis, and vascular cylinder (Figs. 2 and 3). The cortex was only two cell layers thick, (epidermis and subepidermal layer) in all of the roots examined. Lignified xylem cells are especially brilliant using epifluorescence microscopy (Fig. 2). In longitudinal sections, regardless of microscopic methods, the phloem cells are difficult to clearly identify (Fig. 2). The pericycle, the outermost layer of the vascular cylinder from which root initials form, was not distinguishable in any of the sections.

Cross section of a mature root viewed in phase contrast microscopy is presented in Fig. 3. Cross sections viewed in either epifluorescence or bright field microscopy exposed the brightly fluorescing casparian strip in the endodermal layer, the presence of secondary xylem, the tetrarch arrangement of the primary xylem, and the phloem between the xylem poles (Finn, 1989).

Cranberry root anatomy was affected by both the N-form and $\mathrm{pH}$ treatments. Root anatomy of plants receiving $\mathrm{NH}_{4}-\mathrm{N}$, either alone or in combination with $\mathrm{NO}_{3}-\mathrm{N}$, appeared similar. Roots from the $\mathrm{NO}_{3}-\mathrm{N}$-only regime, regardless of $\mathrm{pH}$, differed from those in the $\mathrm{NH}_{4}-\mathrm{N}$ regimes. The epidermal and subepidermal layers stained more darkly in roots receiving only $\mathrm{NO}_{3}-\mathrm{N}$, probably indicating denser cytoplasm. The epidermal cells viewed in longitudinal section were nearly isodiametric, whereas roots from $\mathrm{NH}_{4}-\mathrm{N}$ treatments had rectangular epidermal cells. This variation in the epidermal layer was probably a result of less cell elongation in the $\mathrm{NO}_{3}-\mathrm{N}$ treatment. The cells in the subepidermal layer stained darker, but the staining pattern was not constant throughout the entire cell. In longitudinal sections observed under epifluorescence (Fig. 2), large accumulations of fluorescing granules were apparent in the subepidermal layer. Consistent observations of these granules verified that: 1) They fluoresced similarly to the granules in the root tips, but those in the latter were not localized within a specific area of the cells or strictly within the root cap cells, nor were they affected by $\mathrm{N}$-form; 2) they were never observed in the $\mathrm{NH}_{4}-\mathrm{N}$-only treatments, and were only occasionally observed singly in the $\mathrm{NH}_{4} / \mathrm{NO}_{3}-\mathrm{N}$ treatments; 3) solution $\mathrm{pH}$ had no effect on their occurrence; 


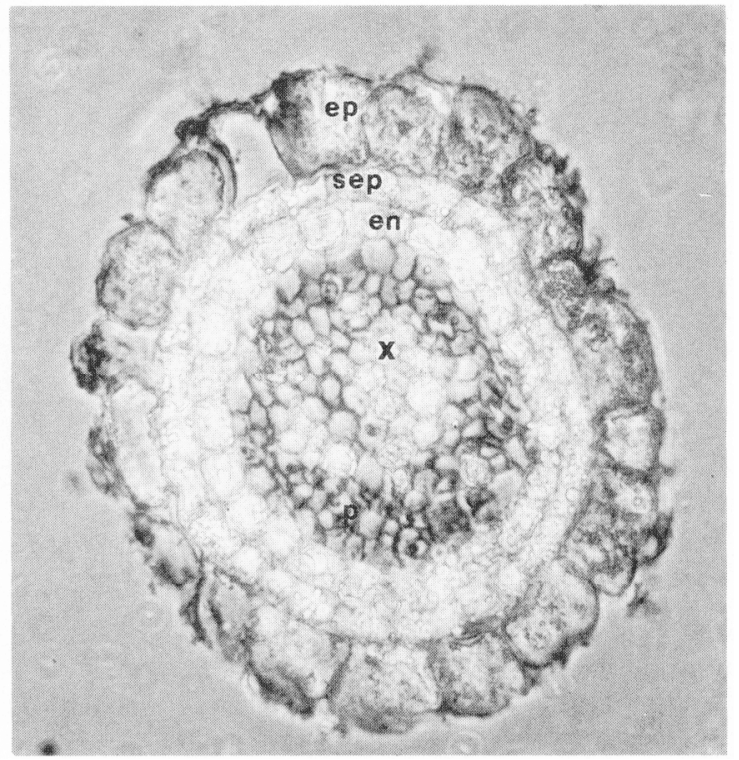

Fig. 3. Photomicrograph of a V. macrocarpon root in cross section ( $\times 400$, phase contrast) from plants grown with only $\mathrm{NH}_{4}-\mathrm{N}$ at $\mathrm{pH}$ 4.5. ep = Epidermal layer, en = endodermal layer, sep $=$ subepidermal layer, $x=x y l e m$, and $p=$ phloem.

4) they were not easily observed with bright field or phase contrast microscopy under lower magnification $(\times 100$ or $\times 400)$; 5) from one to many granules were visible in almost every subepidermal cell with epifluorescence (Fig. $2)$; 6) the granules were readily located in the cell with bright field or phase contrast microscopy at higher magnification $(\times 1000)$, but their presence became readily apparent only with epifluorescence; 7) the granules appeared within the cell walls, on the periphery of the cells in the subepidermal layer (Fig. 2); 8) the granules occurred on the centripetal side of the subepiderrnal cells (Fig. 2).

Tree methods-potassium iodide staining, FASGA staining (Revilla et al., 1986), and crossed polarizing filters-were used to determine whether these granules were starch. Sections were stained with either potassium iodide or FASGA, but the granules did not stain as would starch. Using two crossed polarizing filters, starch may also be identified by a luminous appearance except for a dark cross (Esau, 1960; Fahn, 1982). This approach also failed to identify these granules as starch, as no dark crosses were observed in any of them. Thus, the nature of these granules still remains unclear.

Roots in this study, as those of Townsend (1967) with Vaccinium corymbosum, which received only $\mathrm{NO}_{3}-\mathrm{N}$, were much darker than those in solutions receiving $\mathrm{NH}_{4}-\mathrm{N}$. There is no obvious relationship between these granules and the dark roots.

Roots of cranberry plants grown at $\mathrm{pH} 6.5$, regardless of $\mathrm{N}$ treatment, were more branched than those grown at $\mathrm{pH} 4.5$. Root initials were rarely observed in roots from the higher $\mathrm{pH}$ treatments, regardless of $\mathrm{N}$-form. This result does not imply that fewer were produced, but, rather, these initials quickly developed into branch roots at the higher $\mathrm{pH}$. Roots grown at $\mathrm{pH} 4.5$ had numerous quiescent root initials and fewer branch roots. The root initials develop just beneath the endodermal layer from the pericycle. Wherever a root initial was observed, the overlying epidermal, subepidermal, and endodermal layers were consistently more darkly stained, When these initials developed into branch roots, they forcefully emerged through the three overlying cell layers.

The variation in root initial development under the two $\mathrm{pH}$ regimes was not unexpected based on the observed differences in root system morphology. The granules produced in the supepidermal cell layer when the plants were not supplied with $\mathrm{NH}_{4}-\mathrm{N}$ are intriguing, but their nature and role remain undetermined. Whether the granules in all root tips are the same as the granules in the subepidermal layer of the roots receiving only $\mathrm{NO}_{3}-\mathrm{N}$ is unknown.

\section{Literature Cited}

Addoms, R.M. and F.C. Mounce. 1932. Further notes on the nutrient requirements and the histology of the cranberry, with specific reference to sources of nitrogen. Plant Physiol. 7:643656.

Esau, K. 1960. Anatomy of seed plants. Wiley, New York. p. 170-188.

Fahn, A. 1982. Plant anatomy. 3rd ed. Pergamon, New York. p. 62-67 and 2\%3-287.

Finn, C.E. 1989. Germplasm sources and screening methods to develop higher $\mathrm{pH}$ tolerance in Vaccinium. PhD Diss., Univ. of Minnesota, St. Paul (Diss. Abstr. 50-09B).

Marschner, H. 1986. Mineral nutrition in higher plants. Academic, New York. p. 429-446.

Medappa, K.C. and M.N. Dana. 1970. The influence of $\mathrm{pH}, \mathrm{Ca}, \mathrm{P}$, and $\mathrm{Fe}$ on the growth and composition of the cranberry plant. Soil Sci. 109:250-253.

Moore, R. and M.L. Evans. 1986. How roots perceive and respond to gravity. Amer. J. Bot. 73:574-587.

Nieuwdorp, P.J. 1969. Some investigations on the mycorrhiza of Calluna, Erica, and Vaccinium. Acta Bot. Neerl. 18:180-196.

Revilla, M.A., D. Toliva, and J.F. Tarrago. 1986. A new and permanent staining method for starch granules using fluorescence microscopy. Stain Technol. 61:151-154.

Rosen, C.J., D.L. Allan, and J.J. Luby. 1990. Influence of nitrogen form and solution $\mathrm{pH}$ on growth and nutrition of two Vaccinium clones. J. Amer. Soc. Hort. Sci. 115:83-89.

Salisbury, F.B. and C.W. Ross. 1985. Plant physiology. 3rd ed. Wadsworth, Belmont, Calif. p. 261-262.

Townsend, L.R. 1967. Effect of ammonium nitrogen and nitrate nitrogen, separately and in combination, on the growth of the highbush blueberry. Can. J. Plant Sci. 47:555-562.

Townsend, L.R. 1969. Influence of form of nitrogen and $\mathrm{pH}$ on growth and nutrient levels in the leaves and roots of the lowbush blueberry. Can. J. Plant Sci. 49:333-338.

Townsend, L.R. 1971. Effect of acidity on growth and nutrient composition of the highbush blueberry. Can. J. Plant Sci. 51:385-390. 